\title{
Genetic Variation among Robusta Coffee Genotypes for Growth and Yield Traits in Ghana
}

\author{
Abraham Akpertey $^{1}$, Esther Anim-Kwapong ${ }^{1,2}$ \& Atta Ofori ${ }^{1}$ \\ ${ }^{1}$ Cocoa Research Institute of Ghana, New Tafo-Akim, ER, Ghana \\ ${ }^{2}$ Seed Production Division, Ghana Cocoa Board, Accra, Ghana \\ Correspondence: Abraham Akpertey, Cocoa Research Institute of Ghana, P. O. Box 8, New Tafo-Akim, E/R, \\ Ghana. Tel: 233-556-913-267. E-mail: aakpertey@yahoo.com; abraham.akpertey@crig.org.gh
}

\author{
Received: January 2, $2018 \quad$ Accepted: February 3, $2018 \quad$ Online Published: March 15, 2018 \\ doi:10.5539/jas.v10n4p138 URL: https://doi.org/10.5539/jas.v10n4p138
}

\begin{abstract}
Quantifying the level of variation and estimates of genetic parameters are important to make informed decisions regarding the improvement of agronomic traits in Coffea canephora. The objectives of the present study were to assess the growth and yield performance of 54 C. canephora clones derived through ortet selection, based on yield from a previous hybrid trial; estimate genetic parameters of growth traits (stem diameter, height, span, number of laterals, length of laterals and diameter of laterals), and yield; and determine the relationship between yield and the growth traits. The clones were planted in the field in 2009 using a randomized complete-block design with three replications. Significant $(p<0.01)$ clone effects for all traits and broadsense heritability range of 0.15 (mean yield of last 3 productive years)- 0.43 (diameter of laterals) were observed. Stem diameter was moderately and positively correlated with early years' yield $(2012 / 13$ mean yield, $r=0.49 ; p<0.001)$, late years' yield (2014 to 2016 mean yield, $r=0.44 ; p<0.001)$, and mean yield across five years $(r=0.42 ; p=0.001)$. Relatively high genotypic coefficient of variation and expected genetic advance values were obtained for the evaluated traits, which indicated a high probability of success of selection for these traits.
\end{abstract}

Keywords: clone, Coffea canephora, genetic parameters, genetic variation, heritability

\section{Introduction}

Coffee, a member of the family Rubiaceae, belongs to the genus Coffea that comprises $>105$ species (Medina-Filho et al., 2007), which are prevalent in Africa, including the island of Madagascar (Prakash et al., 2005). Commercial coffee production relies on two main species, Coffea arabica L. and C. canephora Pierre, which are responsible for approximately $2 / 3$ and $1 / 3$ of the global crop, respectively (ICO, 2016). The $C$. canephora, also referred to as Robusta coffee, is a diploid species $(2 n=22)$, characterized by higher productivity and caffeine content, better growth at lower altitude, and greater tolerance to pests, diseases and drought than $C$. arabica (DaMatta et al., 2007). Robusta is the main type of coffee cultivated in Ghana.

Coffea canephora is an out-crossing crop and one of the most important breeding methods used to increase production of such species is hybrid breeding to exploit heterosis. However, the potential benefit of heterosis in hybrid breeding programs depends on combining genetically distant gene pools based on a positive correlation between heterotic effect and genetic distance as has been demonstrated in Arabica coffee (Wassu, 2011), cocoa (Dias et al., 2003), oilseed (Riaz et al., 2001) and maize (Betrán et al., 2003). For their efficient utilization, evaluation of clones for key agronomic traits before they are selected for use in a breeding program is, therefore, important. This enables breeders to choose parents effectively.

Knowledge of relationships among traits and genetic parameters, including heritability, is important for potential parental clone selection for hybrid development in a coffee breeding program. In Ghana, besides the development of hybrid planting materials for farmers, the deployment of clonal planting materials to supplement hybrid seedlings is important in improving and increasing the total national Robusta coffee production. One adopted strategy for clone development in clonally propagated crops is to follow a cycle of progeny testing and clonal evaluation of best ortets in a recurrent selection program (Brown et al., 1988; Kawano et al., 1998). In that regard, breeding of $C$. canephora has traditionally been based on the selection of full-sib families and identification of clones in the best hybrid families (Montagnon et al., 1998). If such selection is to be successful, 
it is necessary to estimate genetic parameters of important agronomic and morphological traits in a breeding population.

Additionally, information on the amount of variation in a population with respect to key growth and yield traits is important, as it aids in properly designing crop improvement strategies and management practices to improve productivity (Reuben et al., 2003). Productivity can be enhanced through genetic improvement (Bouharmont et al., 1986), which requires evaluation and comparison of clonal or hybrid yields. Theoretically, the yielding ability of any plant material should be estimated from the yields cumulated across the lifetime of coffee trees, which could be several years of observations (Cilas et al., 2006). However, in practice, new clones and hybrids have to be produced by plant breeders quickly and frequently to satisfy the demands of farmers for increased productivity (Cilas et al., 2006). To do this, it is important to know the relationship between growth traits and yield from early and late growth stages, to effectively predict future and cumulative yields of recommended varieties.

Perennial plant species, such as coffee, exhibit pronounced annual yield fluctuations, resulting in biennial yield cycle; overlapping generations; expression of traits across several years and differences in earliness and productive longevity (Sera, 2001). These agronomic peculiarities make the breeding and improvement of $C$. canephora a difficult and slow process, requiring several years of yield data, typically 5 to 7 years, to practice selection in a generation (Anim-Kwapong et al., 2011a). To improve yield and/or any other agronomic trait, it is important to estimate genetic and environmental effects for successful selection of superior genotypes. Accurate estimates of components of variance provide a basis for critically evaluating breeding and testing procedures (Reuben et al., 2003). Furthermore, estimations of genetic parameters also enhance breeder's understanding of the nature of gene action and assessment of expected progress from selection and help identify the best selection method to be adopted (Oliveira et al., 2008). Heritability estimates help in designing appropriate selection procedures for improving clones (Reuben et al., 2003). To facilitate breeding efforts, several studies have reported estimates of genetic parameters determined from C. canephora clones (Leroy et al., 1993, 1997; Fonseca, 1999; Cilas et al., 2000; E. Anim-Kwapong \& G. J. Anim-Kwapong, 2012) and seedlings (Mistro et al., 2004; Montagnon et al., 2003; Cilas et al., 2003).

Although there have been a number of studies on the significance of genetic parameters in facilitating breeding of Robusta coffee, there exist some inconsistencies in the magnitude of genetic parameters of growth and yield traits to direct effective and efficient selection. Furthermore, the most suitable stage at which selection would be most effective (i.e. early or late in the breeding program) in Robusta coffee for some agronomic and yield traits has not been clearly established. Therefore, the objectives of the study were to assess the performance of $C$. canephora clones for growth traits (stem diameter, height, span, number of laterals, length of laterals and diameter of laterals) and yield; estimate genetic parameters of the growth and yield traits; and determine the relationship between yield and the growth traits.

\section{Materials and Methods}

\subsection{Plant Material}

The study utilized 54 Robusta coffee clones developed by ortet selection (combined family-individual selection), based on yield, and following a coffee progeny trial involving 30 progenies derived from a $6 \times 5$ factorial crossing scheme at the Cocoa Research Institute of Ghana (CRIG). The progeny trial was evaluated between 1999 and 2006, after which the highest-yielding progenies were identified on the basis of yield. The best plants from the best progenies were selected and cuttings were obtained from them to generate the clones evaluated in this study. In generating the experimental materials, single-node cuttings of each clone were rooted in propagators filled with 1:1 mixture of sand and rice husk, and nursed in nursery bags for six months before they were transplanted in the field.

\subsection{Study Site}

The clones generated were planted at the experimental fields of the CRIG, Tafo (latitude $06^{\circ} 13^{\prime} \mathrm{N}$, longitude $0^{\circ} 22^{\prime} \mathrm{W}$ ), which, situated in the Eastern Region of Ghana, is approximately 220 meters above sea level. The soil at Tafo is sandy loam, classified as Haplic Luvisol, brown to yellowish red, well drained, and developed in situ from weathered materials of hornblende granodiorite (Adu \& Asiamah, 1992). The information on weather parameters during the period of the study was obtained from the meteorological station of CRIG (Table 1). The experimental plot used was obtained after clearing a field that had not been cropped for about 10 years. 
Table 1 . Total yearly rainfall, mean temperature and relative humidity during the period of the study between 2009 and 2016

\begin{tabular}{llllll}
\hline \multirow{2}{*}{ Year } & \multirow{2}{*}{$\begin{array}{l}\text { Total rainfall } \\
(\mathrm{mm})\end{array}$} & Number of days & \multicolumn{2}{c}{ Mean temperature $\left({ }^{\circ} \mathrm{C}\right)$} & $\begin{array}{l}\text { Minimum } \\
(0700 \mathrm{~h})\end{array}$ \\
\hline 2009 & 1176.6 & 118.0 & 22.3 & $\begin{array}{l}\text { Maximum } \\
(1500 \mathrm{~h})\end{array}$ & $\begin{array}{l}\text { Mean relative humidity } \\
\text { at } 1500 \mathrm{~h}(\%)\end{array}$ \\
2010 & 1609.6 & 141.0 & 22.6 & 31.6 & 66.5 \\
2011 & 1789.8 & 135.0 & 21.7 & 31.7 & 69.6 \\
2012 & 1317.1 & 128.0 & 20.9 & 31.6 & 64.4 \\
2013 & 1516.2 & 123.0 & 19.4 & 31.8 & 65.9 \\
2014 & 1748.8 & 132.0 & 18.5 & 31.6 & 63.0 \\
2015 & 1088.1 & 106.0 & 18.8 & 32.3 & 68.0 \\
2016 & 1642.9 & 111.0 & 20.4 & 32.6 & 60.9 \\
\hdashline Mean & 1486.1 & 124.3 & 20.6 & 31.8 & 62.9 \\
\hline
\end{tabular}

\subsection{Experimental Design and Field Establishment Procedures}

The 54 Coffea canephora clones were planted in the field in June 2009 using a randomized complete-block design with three blocks or replications. A single-tree randomization approach was followed, such that four to five ramets per clone per block (with a total of 14 ramets per clone across the 3 blocks) were planted at a spacing of $2 \mathrm{~m} \times 3 \mathrm{~m}$. Gliricidia sepium was planted between rows at a spacing of $4 \mathrm{~m} \times 6 \mathrm{~m}$ to provide permanent shade for the coffee clones during the period of the experiment. Each year, the Gliricidia shade was managed by pruning to avoid over-shading of the coffee clones. No fertilizer was applied and standard crop-management practices were followed during the period of the experiment. To assess uniformly the genetic differences among the clones, the plants were allowed to grow on one or two stems that had developed from the single-node cuttings.

\subsection{Traits Evaluated}

Plant height (m) was measured, with a meter rule, from the soil surface to the apex of the plant. Diameter of the main stem ( $\mathrm{mm}$ ) was measured $10 \mathrm{~cm}$ above the soil surface with electronic calipers. Span $(\mathrm{m})$ was taken as the width of the canopy, where tree canopy was the widest. Diameter of laterals $(\mathrm{mm})$ was measured with electronic calipers as the mean diameter of six random laterals that extended $10 \mathrm{~cm}$ from the main stem. The number of laterals per tree was counted and the length of laterals (m) was measured from the point of attachment to the main stem to the apex of the lateral using the mean length of six laterals selected randomly. Whenever there were multiple stems, stem diameter was calculated according to Stewart and Salazar (1992) and span was measured only on the biggest stem. Stem diameter, height, number of laterals, diameter of laterals, length of laterals and span were measured at yearly intervals from 2010 to 2013. Cherry weight (typically from October to January) was recorded for each tree for five productive years from 2012 to 2016 and transformation of cherry weight to clean coffee yield was done using a conversion factor of 0.22 (Wellman, 1961; Coste, 1992).

\subsection{Statistical Analyses}

An analysis of variance (ANOVA) was performed for each trait based on the following linear model:

$$
Y_{i j}=\mu+c_{i}+b_{j}+e_{i j}
$$

where, $Y_{i j}$ is the phenotypic measurement of the $i$ th clone in the $j$ th block for trait $\mathrm{Y} ; \mu$ is the population mean; $c_{i}$ is the fixed effect of the $i$ th clone; $b_{j}$ is the random effect of the $j$ th block; and $e_{i j}$ is the random error. However, to obtain variance components and associated standard errors, clones were treated as a random factor. The variance component estimates were used to estimate broad-sense heritability $\left(h_{b}^{2}\right)$ as the ratio of genotypic variance component ('clone' variance) to phenotypic variance (Falconer, 1974).

$$
h_{b}^{2}=\frac{\sigma_{g}^{2}}{\sigma_{P}^{2}}
$$

where, $h_{b}{ }^{2}=$ broad-sense heritability; $\sigma_{g}{ }^{2}=$ genotypic variance component; and $\sigma_{P}{ }^{2}=$ phenotypic variance $\left(\sigma_{g}{ }^{2}\right.$; genotypic variance component $+\sigma_{e}^{2}$; error variance component).

Genotypic coefficient of variation (GCV) and phenotypic coefficient of variation (PCV) were estimated following Burton (1952) as: 


$$
\mathrm{GCV}=\frac{\sqrt{\sigma_{g}^{2}}}{M} \times 100 ; \text { and } \mathrm{PCV}=\frac{\sqrt{\sigma_{P}^{2}}}{M} \times 100
$$

where, $\mathrm{M}$ is trait mean.

Expected genetic advance (Gs) under selection for each trait was calculated following Allard (1960) as:

$$
\mathrm{Gs}=(\mathrm{k})\left(\sigma_{P}\right)\left(h_{b}^{2}\right)
$$

where, $\mathrm{k}=$ selection differential which varies with selection intensity (values of $\mathrm{k}$ used were 2.42, 2.06, 1.76, 1.4 and 1.16 for selection intensities of 2, 5, 10, 20 and 30, respectively) and $\sigma_{P}=$ phenotypic standard deviation. The Gs was expressed as a percentage of each trait mean for reporting (Kang et al., 1983).

Vegetative growth data (stem diameter, height, span, number of laterals, length of laterals and diameter of laterals) used in the analyses included the mean trait measurements collected across a 4-year period (2010 to 2013) when the plants had attained maximum expansion, whereas the yield data spanned a 5-year period (2012 to 2016). The mean stem diameter, height, span, number of primary branches prior to maximum expansion and mean yield for the first two years, mean yield for the last three years and mean yield for the five productive years were subjected, separately, to analysis of variance (ANOVA). Prior to ANOVA, normality of each dataset was checked by plotting residuals. Pearson's phenotypic correlation analysis was performed to assess the association between the growth and yield traits. All statistical analyses were performed using the GenStat statistical software, version 12 (VSN International Ltd, Hemel Hempstead, UK).

\section{Results and Discussion}

\subsection{Weather Characteristics of the Experimental Site during the Study Period}

The period of the experiment received an average rainfall of 1,486 mm per annum (Table 1), which was within the optimum required annual rainfall range $(1200-1800 \mathrm{~mm})$ for growth and development of $C$. canephora, although Robusta adapts better to annual rainfall of $>2000 \mathrm{~mm}$ (Coste, 1992). During the period of the experiment, the highest and least amounts of rainfall were received in 2011 and 2015, respectively (Table 1). The numbers of rainy days were fairly similar across years; the least number of rainy days occurred in 2015, which, unsurprisingly, recorded the least amount of annual rainfall during the period of the experiment. Generally, in all years, there was a pronounced 4-month dry season that occurred between November and February (data not presented). The mean annual temperature recorded during the period of the experiment ranged from 20.6 to $31.8^{\circ} \mathrm{C}$ (Table 1). Although suitable temperatures for plant growth change with the phenological stage of coffee (DaMatta \& Ramalho, 2006), Robusta coffee prefers an optimum temperature range of $24-30{ }^{\circ} \mathrm{C}$, and not below $15{ }^{\circ} \mathrm{C}$ (Willson, 1999). Temperatures of up to $30^{\circ} \mathrm{C}$ have been found to be necessary for floral bud initiation in Robusta coffee (Barros et al., 1999). High temperatures, nonetheless, can be harmful to the coffee plant, especially if the air is dry (Coste, 1992). In general, the weather characteristics observed during the period of the experiment can be described as satisfactory for Robusta coffee.

\subsection{Agronomic Performance and Variation among Robusta Coffee Clones}

Highly significant $(p<0.01)$ variation for stem diameter, height, span, number of laterals, length of laterals, diameter of laterals and yield was observed among the 54 C. canephora clones evaluated (Table 2). This observation indicated the presence of substantial variability among the tested Robusta coffee clones and the possibility of selection for high-performing genotypes for all traits studied. Even though the experiment was established on a field which had not been cropped for about 10 years before the initiation of the experiment, there were significant block effects for most of the vegetative growth traits (stem diameter, height, number of laterals and diameter of laterals) and early yield (20012/13 mean yield), but not for mean yield across five years (Table 2). This suggested that the location was heterogeneous and as such blocking controlled heterogeneity effectively. 
Table 2. Mean squares for growth and yield traits of 54 Robusta coffee clones evaluated

\begin{tabular}{|c|c|c|c|c|c|c|c|c|c|c|}
\hline \multirow{2}{*}{$\begin{array}{l}\text { Source of } \\
\text { variation }\end{array}$} & \multirow[b]{2}{*}{$\mathrm{df}$} & \multicolumn{9}{|c|}{ Trait } \\
\hline & & $\begin{array}{l}\text { Stem diam } \\
(\mathrm{mm})\end{array}$ & $\begin{array}{l}\text { Height } \\
\text { (m) }\end{array}$ & $\begin{array}{l}\text { No. of } \\
\text { laterals }\end{array}$ & $\begin{array}{l}\text { Diam lat } \\
(\mathrm{mm})\end{array}$ & $\begin{array}{l}\text { Length lat } \\
\text { (m) }\end{array}$ & $\begin{array}{l}\text { Span } \\
(\mathrm{m})\end{array}$ & $\begin{array}{l}\mathrm{Y} 12 / 13 \\
(\mathrm{t} / \mathrm{ha} / \mathrm{yr})\end{array}$ & $\begin{array}{l}\text { Y14-16 } \\
\text { (t/ha/yr) }\end{array}$ & $\begin{array}{l}\text { Y12-16 } \\
(\mathrm{t} / \mathrm{ha} / \mathrm{yr})\end{array}$ \\
\hline Block & 2 & $824.70 * *$ & $0.60 * *$ & $1895.30 * *$ & $8.87 *$ & $0.002 \mathrm{~ns}$ & $0.17 \mathrm{~ns}$ & $1.39 * *$ & $2.51 \mathrm{~ns}$ & $0.38 \mathrm{~ns}$ \\
\hline Clone & 53 & $248.91^{* *}$ & $0.27 * *$ & $432.70 * *$ & $4.53 * *$ & $0.17 * *$ & $0.20 * *$ & $1.12 * *$ & $2.63 * *$ & $1.82 * *$ \\
\hline Error & 106 & 46.48 & 0.07 & 118.9 & 0.46 & 0.02 & 0.06 & 0.21 & 0.88 & 0.55 \\
\hline CV (\%) & & 23.7 & 18.8 & 29.9 & 17.2 & 20.7 & 17.6 & 60.2 & 45.8 & 49.7 \\
\hline
\end{tabular}

Note. ${ }^{*}, * *=$ significant at $5 \%$ and $1 \%$ probability level, respectively; $\mathrm{ns}=$ not significant; $\mathrm{CV}(\%)=$ coefficient of variation; Stem diam $=$ stem diameter measured $10 \mathrm{~cm}$ above the soil surface with electronic calipers at yearly intervals from 2010 to 2013; Diam lat $=$ diameter of laterals taken as the mean diameter of six random laterals 10 $\mathrm{cm}$ from the main stem measured with electronic calipers at yearly intervals from 2010 to 2013; Length lat = length of laterals measured as the mean length of six random laterals from the point of attachment to the main stem to the apex of the lateral at yearly intervals from 2010 to 2013; Y12/13 = 2012 and 2013 mean yield of Robusta coffee clones evaluated; Y14-16 = 2014 to 2016 mean yield of evaluated Robusta coffee clones; Y12-16 = 2012 to 2016 mean yield of evaluated Robusta coffee clones.

On average, stem diameter varied from $24.1 \mathrm{~mm}$ in clone $\mathrm{H} 459$ to $43.3 \mathrm{~mm}$ in clone H204, with a mean of 45.2 $\mathrm{mm}$ for all clones evaluated (Table 3). The clones with the smallest and largest diameter of laterals were H242 $(4.0 \mathrm{~mm})$ and H643 $(7.2 \mathrm{~mm})$, respectively, with a mean of $5.3 \mathrm{~mm}$. Height, on the other hand, ranged from 1.3 $\mathrm{m}$ to $1.9 \mathrm{~m}$ among the Robusta coffee clones evaluated. The mean length of laterals was $0.9 \mathrm{~m}$, ranging from 0.7 (H116) to $1.2 \mathrm{~m}$ (H1069); and the number of laterals averaged 41, ranging from 25.2 for H885 to 55.4 for H146. Span also ranged from $1.3 \mathrm{~m}$ (H242, H543) to $1.8 \mathrm{~m}$ (H907, H1069), with a mean of $1.5 \mathrm{~m}$ (Table 3). Reuben (2003), who evaluated six Robusta coffee clones and measured growth traits three years after planting, reported similar values for plant height and stem diameter, but slightly lower span than what was observed in the current study. Furthermore, there was much less variation in the growth traits measured in the study by Reuben (2003) compared with what was observed in this study. This difference could mainly be attributable to the fewer clones in the Reuben (2003) study compared with the 54 evaluated in the present study. The mean early-year yields (first two productive years) ranged between $0.1(\mathrm{H} 253)$ and $1.6 \mathrm{t} / \mathrm{ha} / \mathrm{yr}$ (H957), with a mean of $0.5 \mathrm{t} / \mathrm{ha} / \mathrm{yr}$ (Table 3). Anim-Kwapong et al. (2011a) reported relatively higher mean early-year yields (1.8 t/ha) of Robusta coffee clones evaluated across a 9-year period in Ghana. This disparity between the two studies could, in part, be attributable to the different genotypes evaluated in the two studies as both studies were carried out at Tafo.

The last three years' mean yield was relatively higher than the first two years' mean yield for the present study. It ranged from $1.0 \mathrm{t} / \mathrm{ha} / \mathrm{yr}$ for clones H729 and H556 to $3.3 \mathrm{t} / \mathrm{ha} / \mathrm{yr}$ for clone H1069, with a mean of $2.2 \mathrm{t} / \mathrm{ha} / \mathrm{yr}$. Typically, perennial tree crops reach their maximum production in later years when tree canopy is fully expanded for significant sunlight interception and photosynthetic activity, thus the relatively higher yields observed for later years in our study. There was significant variation among the 54 Robusta coffee clones for mean yield across five years, with more than a three-fold difference between the lowest (H556 recording $0.7 \mathrm{t} / \mathrm{ha} / \mathrm{yr}$ ) and highest (H480 recording $2.5 \mathrm{t} / \mathrm{ha} / \mathrm{yr}$ ) yielding clones (Table 3). A similar yield range was reported by Montagnon et al. (2000) among Robusta coffee clones evaluated in the Ivory Coast. Similarly, Anim-Kwapong et al. (2011b), after evaluating Robusta coffee clones, reported mean yields across a 7-year period comparable with what is reported in the current study.

The highest-yielding 10 Robusta coffee clones were similar in mean yield across a 5-year yield-recording period (2012 to 2016), but there were only small differences among some of them for stem diameter, height, span, number of laterals, length of laterals and diameter of laterals (Table 3). For the highest-yielding 10 and lowest-yielding 10 clones, there was a very high level of variation among clones evaluated for average yield across a 5-year period with $>$ three-fold difference between the least-yielding clone (H556) and the highest-yielding clone $(\mathrm{H} 480)$. On the contrary, there was no significant $(p>0.05)$ difference between the highest (H480) and lowest (H556) yielding clones for mean stem diameter growth (34.1 mm vs. $29.3 \mathrm{~mm}$ ), and diameter of laterals $(6.0 \mathrm{~mm}$ vs. $5.1 \mathrm{~mm})$, but there was a significant difference for yield for the last three years $(2.8 \mathrm{t} / \mathrm{ha} / \mathrm{yr}$ vs. $1.0 \mathrm{t} / \mathrm{ha} / \mathrm{yr})$. Also, there were no significant $(p>0.05)$ differences between the lowest-yielding clone and highest-yielding clone for height ( $1.6 \mathrm{~m}$ vs. $1.4 \mathrm{~m})$, number of laterals (38.1 vs. 42.3$)$, length of laterals $(0.9 \mathrm{~m}$ vs. $1.0 \mathrm{~m})$, span $(1.5 \mathrm{~m}$ vs. $1.6 \mathrm{~m})$ and early yield $(0.4 \mathrm{t} / \mathrm{ha} / \mathrm{yr}$ vs. $0.3 \mathrm{t} / \mathrm{ha} / \mathrm{yr})($ Table 3$)$. The lack of difference between the highest and lowest yielding clones for the growth traits (stem diameter growth, diameter 
of laterals, height, number of laterals, length of laterals and span) and early yield suggests that for the set of clones evaluated, one has to be careful in selecting for yield based on the afore mentioned traits early in a breeding programme.

Table 3. Mean growth and yield trait measurements of the top and bottom ten yielding Robusta coffee clones evaluated

\begin{tabular}{|c|c|c|c|c|c|c|c|c|c|}
\hline Clone & $\begin{array}{l}\text { Stem diam } \\
(\mathrm{mm})\end{array}$ & $\begin{array}{l}\text { Height } \\
(\mathrm{m})\end{array}$ & $\begin{array}{l}\text { No. of } \\
\text { laterals }\end{array}$ & $\begin{array}{l}\text { Diam lat } \\
(\mathrm{mm})\end{array}$ & $\begin{array}{l}\text { Length lat } \\
\text { (m) }\end{array}$ & $\begin{array}{l}\text { Span } \\
\text { (m) }\end{array}$ & $\begin{array}{l}\mathrm{Y} 12 / 13 \\
(\mathrm{t} / \mathrm{ha} / \mathrm{yr})\end{array}$ & $\begin{array}{l}\text { Y14-16 } \\
\text { (t/ha/yr) }\end{array}$ & $\begin{array}{l}\text { Y12-16 } \\
(\mathrm{t} / \mathrm{ha} / \mathrm{yr})\end{array}$ \\
\hline \multicolumn{10}{|c|}{ Highest-yielding 10 clones } \\
\hline $\mathrm{H} 480$ & 34.1 & 1.4 & 42.3 & 6.0 & 1.0 & 1.6 & 0.3 & 2.8 & 2.5 \\
\hline H1069 & 37.4 & 1.8 & 41.9 & 6.4 & 1.2 & 1.8 & 0.3 & 3.3 & 2.2 \\
\hline H682 & 32.1 & 1.6 & 43.3 & 4.8 & 0.9 & 1.5 & 0.3 & 2.8 & 2.2 \\
\hline H907 & 41.7 & 1.8 & 37.3 & 5.9 & 1.1 & 1.8 & 0.5 & 2.8 & 2.1 \\
\hline $\mathrm{H} 250$ & 37.1 & 1.5 & 48.6 & 5.4 & 1.0 & 1.6 & 0.7 & 2.6 & 2.1 \\
\hline H146 & 40.3 & 1.8 & 55.4 & 5.8 & 1.0 & 1.7 & 0.9 & 2.6 & 2.1 \\
\hline H266 & 32.3 & 1.5 & 42.1 & 5.4 & 0.9 & 1.6 & 0.4 & 2.6 & 2.1 \\
\hline H395 & 39.9 & 1.9 & 55.1 & 5.0 & 1.0 & 1.5 & 0.9 & 2.6 & 2.1 \\
\hline H957 & 39.1 & 1.5 & 45.1 & 5.1 & 0.9 & 1.5 & 1.6 & 2.2 & 2.0 \\
\hline $\mathrm{H} 246$ & 35.5 & 1.6 & 45.1 & 5.4 & 1.0 & 1.6 & 0.7 & 2.9 & 2.0 \\
\hline \multicolumn{10}{|c|}{ Lowest-yielding 10 clones } \\
\hline H55 & 33.0 & 1.4 & 37.5 & 5.4 & 0.9 & 1.5 & 0.3 & 1.9 & 1.3 \\
\hline $\mathrm{H} 253$ & 31.1 & 1.5 & 40.0 & 5.3 & 1.1 & 1.6 & 0.1 & 1.8 & 1.3 \\
\hline $\mathrm{H} 765$ & 34.2 & 1.6 & 38.8 & 5.4 & 0.9 & 1.5 & 0.4 & 1.8 & 1.2 \\
\hline $\mathrm{H} 453$ & 32.1 & 1.6 & 37.2 & 5.1 & 0.8 & 1.4 & 0.2 & 1.7 & 1.2 \\
\hline H429 & 32.0 & 1.3 & 44.8 & 5.5 & 0.9 & 1.5 & 0.3 & 1.6 & 1.1 \\
\hline H317 & 25.9 & 1.4 & 36.0 & 4.7 & 0.9 & 1.5 & 0.2 & 1.8 & 1.1 \\
\hline H543 & 29.2 & 1.4 & 38.2 & 4.7 & 0.8 & 1.3 & 0.2 & 1.2 & 0.9 \\
\hline $\mathrm{H} 242$ & 24.2 & 1.3 & 37.7 & 4.0 & 0.8 & 1.3 & 0.3 & 1.4 & 0.9 \\
\hline H729 & 31.6 & 1.7 & 41.1 & 4.5 & 0.8 & 1.5 & 0.4 & 1.0 & 0.8 \\
\hline H556 & 29.3 & 1.6 & 38.1 & 5.1 & 0.9 & 1.5 & 0.4 & 1.0 & 0.7 \\
\hline SED $_{P<0.05}$ & 2.8 & 0.1 & 4.5 & 0.3 & 0.1 & 0.1 & 0.2 & 0.4 & 0.3 \\
\hline
\end{tabular}

Note. Stem diam $=$ stem diameter measured $10 \mathrm{~cm}$ above the soil surface with electronic calipers at yearly intervals from 2010 to 2013; Diam lat = diameter of laterals taken as the mean diameter of six random laterals $10 \mathrm{~cm}$ from the main stem measured with electronic calipers at yearly intervals from 2010 to 2013; Length lat = length of laterals measured as the mean length of six random laterals from the point of attachment to the main stem to the apex of the lateral at yearly intervals from 2010 to 2013; Y12/13 = 2012 and 2013 mean yield of Robusta coffee clones evaluated; Y14-16 = 2014 to 2016 mean yield of evaluated Robusta coffee clones; Y12-16 = 2012 to 2016 mean yield of evaluated Robusta coffee clones; SED = standard error of differences.

\subsection{Relationship between Vegetative Growth and Yield Traits}

Results of the relationship between vegetative traits (stem diameter, height, number of laterals, diameter of laterals, length of laterals and span) and first two years' mean yield, last three years' mean yield and mean yield across five years using Pearson's correlation coefficient are shown in Table 4. Though significant correlations were observed between vegetative traits and yield, all correlations were weak; as such, selection should be based on performance of clones for each trait measured. Moderate but significant correlations were observed between stem diameter and mean yield of the first two years' $(r=0.49, p<0.001)$, last three years' mean yield $(r=0.44$, $p<0.001)$ and mean yield across five years $(r=0.42, p=0.001)$ (Table 4). Height was not significantly correlated with yield in our study. This is contrary to the findings of Marandu et al. (2004), who observed a high significant correlation $(r=0.64, p=0.01)$ between height and mean yield of Robusta coffee clones evaluated across a 5-year period in Tanzania. This disparity between both studies may be due to the different genotypes evaluated for both studies and differences in environment in which the genotypes were evaluated. 
A moderate but significant correlation between number of laterals and the first two years' mean yield ( $r=0.46, p$ $<0.001$ ) was observed. Small but significant correlation coefficients were observed between 5 -year mean yield and diameter of laterals $(r=0.32, p=0.02, \mathrm{n}=54)$, length of laterals $(r=0.31, p=0.02, \mathrm{n}=54)$ and $\operatorname{span}(r=$ $0.33, p=0.02, \mathrm{n}=54$ ) (Table 4). The significant associations observed in this study agree with previous findings in that Robusta coffee yields (Bouharmont et al., 1986; Leroy et al., 1993; Cilas et al., 2006), as well as Arabica coffee yields (Walyaro \& Van der Vossen, 1979; Walyaro, 1983; Cilas et al., 1998) were positively correlated with young plant growth traits.

Because of the heterogeneous and biennial bearing nature of Coffea canephora, yield is typically estimated as a mean of five to seven-year yield of clean coffee per hectare (Anim-Kwapong et al., 2011a). This is a costly and lengthy process. Selection for yield could be facilitated (based on early yield) if high and significant associations were detected between early yields and cumulative yields. For the current study, the correlation between early yield (first 2 years' mean yield) and 5-year mean yield was $0.34(p=0.01)$, indicating that only $11.6 \%$ of the covariation was accounted for. Similar correlations have been reported in earlier studies (Walyaro \& Van Der Vossen 1979; Anim-Kwapong et al., 2011a). On the other hand, the mean yield of the last three yield recording years (2014 to 2016) was highly significantly $(r=0.92, p<0.001)$ associated with the 5 -year mean yield for the Robusta coffee clones evaluated (Table 4). The amount of variation $\left(r^{2}\right)$ explained by the two traits (mean yield for the last three years and 5 -year mean yield) was $84.6 \%$. Therefore, selection decision could possibly be made on the basis of three-year mean yield of clones.

Table 4. Phenotypic correlations $(n=54)$ between vegetative growth traits and yield of 54 Robusta coffee clones evaluated

\begin{tabular}{llll}
\hline Trait & $2012 / 13$ mean yield & 2014 to 2016 mean yield & 2012 to 2016 mean yield \\
\hline Stem diameter $(\mathrm{mm})$ & $0.49(<0.001)$ & $0.44(<0.001)$ & $0.42(0.001)$ \\
Height $(\mathrm{m})$ & $0.26(0.06)$ & $0.19(0.18)$ & $0.17(0.23)$ \\
Number of laterals & $0.46(<0.001)$ & $0.16(0.24)$ & $0.26(0.05)$ \\
Diameter of laterals $(\mathrm{m})$ & $0.23(0.09)$ & $0.34(0.01)$ & $0.32(0.02)$ \\
Length of laterals $(\mathrm{m})$ & $0.25(0.08)$ & $0.38(0.005)$ & $0.31(0.02)$ \\
Span $(\mathrm{m})$ & $0.29(0.04)$ & $0.36(0.008)$ & $0.33(0.02)$ \\
\hline
\end{tabular}

Note. Level of significance in parentheses.

\subsection{Variance Components and Genetic Parameter Estimates}

For all traits investigated in this study, the genetic variance components were smaller than their respective environmental variance components (Table 5 ). Thus, the traits were highly influenced by environmental factors. In this study, the least genotypic variance component $(0.01 \pm 0.003)$ was observed for length of laterals and span,

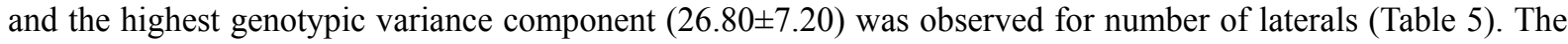
ratio of environmental variance component to genetic variance component indicates the importance of environmental effects in controlling traits. The environmental variance component to genetic variance component ratios for all the traits assessed were positive and greater than 1, indicating variation in the degree of environmental influence on the genotypes (Vencovsky, 1987); however, substantial variability among genotypes was revealed by the wide range between the minimum and maximum values scored for each trait (Table 5) coupled with the significant $(p<0.01)$ clone effect detected for all traits from the ANOVA. This variability would present opportunities for selection and improvement of the traits assessed in the present study.

Moderate to low broad-sense heritability estimates were observed for all traits including yield (Table 5). Similar heritability estimates for the traits evaluated in this study were reported by Srinivasan et al. (1979). On the other hand, Walyaro and Van der Vossen (1979) reported, from a study conducted in Kenya, relatively high heritability for yield in Arabica coffee grown on multiple stems without shade. The present study was under low level of shade provided by Gliricidia sepium. Also, the Robusta coffee clones evaluated in this study were made to grow on single or double stems. The contrasting findings could be attributed to the difference in species, clones, and systems of training coffee. Diameter of laterals had the highest broad-sense heritability of $0.43 \pm 0.18$, which is comparable to earlier reported values of 0.45 and 0.52 in Robusta coffee under drought and non-drought stress, respectively (E. Anim-Kwapong \& G. J. Anim-Kwapong, 2012). 
Table 5. Variance components, estimates of genetic parameters, mean and range of growth and yield traits of 54 Robusta coffee clones evaluated

\begin{tabular}{|c|c|c|c|c|c|c|c|c|}
\hline \multirow{2}{*}{ Trait } & \multicolumn{6}{|c|}{ Genetic parameter } & \multirow{2}{*}{ Mean } & \multirow{2}{*}{ Range } \\
\hline & $\sigma_{g}^{2}$ & $\sigma_{e}^{2}$ & $h_{b}^{2}$ & GCV & $\mathrm{PCV}$ & $\sigma_{e}^{2} / \sigma_{g}^{2}$ & & \\
\hline Diameter of laterals (mm) & $0.34 \pm 0.07$ & $0.46 \pm 0.03$ & $0.43 \pm 0.18$ & 11.14 & 17.01 & 1.3 & 5.3 & $4.0-7.2$ \\
\hline Stem diameter (mm) & $16.97 \pm 4.07$ & $46.47 \pm 2.72$ & $0.27 \pm 0.07$ & 12.05 & 23.30 & 2.7 & 34.2 & $24.1-45.2$ \\
\hline Height (m) & $0.02 \pm 0.004$ & $0.07 \pm 0.004$ & $0.20 \pm 0.04$ & 8.36 & 18.68 & 4.0 & 1.6 & $1.3-1.9$ \\
\hline Length of laterals (m) & $0.01 \pm 0.003$ & $0.02 \pm 0.001$ & $0.34 \pm 0.12$ & 12.16 & 20.74 & 1.9 & 0.9 & $0.7-1.2$ \\
\hline Number of laterals & $26.80 \pm 7.20$ & $118.9 \pm 7.00$ & $0.18 \pm 0.03$ & 12.64 & 29.48 & 4.4 & 41.0 & $25.2-55.4$ \\
\hline Span (m) & $0.01 \pm 0.003$ & $0.06 \pm 0.004$ & $0.16 \pm 0.03$ & 7.13 & 17.59 & 5.1 & 1.5 & $1.3-1.8$ \\
\hline $\mathrm{Y} 12 / 13(\mathrm{t} / \mathrm{ha} / \mathrm{yr})$ & $0.09 \pm 0.02$ & $0.21 \pm 0.01$ & $0.30 \pm 0.09$ & 59.26 & 108.96 & 2.4 & 0.5 & $0.1-1.6$ \\
\hline Y14-16 (t/ha/yr) & $0.15 \pm 0.04$ & $0.88 \pm 0.05$ & $0.15 \pm 0.02$ & 17.58 & 46.17 & 5.9 & 2.2 & $1.0-3.3$ \\
\hline Y12-16 (t/ha/yr) & $0.11 \pm 0.03$ & $0.56 \pm 0.03$ & $0.16 \pm 0.03$ & 20.38 & 50.83 & 5.2 & 1.6 & $0.7-2.5$ \\
\hline
\end{tabular}

Note. Y12/13 = 2012 and 2013 mean yield of Robusta coffee clones evaluated; Y14-16 =2014 to 2016 mean yield of evaluated Robusta coffee clones; Y12-16 = 2012 to 2016 mean yield of evaluated Robusta coffee clones; $\sigma_{g}{ }^{2}=$ genotypic variance component; $\sigma_{e}{ }^{2}=$ error variance component; $h_{b}{ }^{2}=$ broad-sense heritability estimated from the variance components; $\mathrm{GCV}=$ genotypic coefficient of variation; $\mathrm{PCV}=$ phenotypic coefficient of variation.

In general, higher broad-sense heritability estimates were observed for the vegetative growth traits (stem diameter, height, number of laterals, diameter of laterals, length of laterals and span) than for cumulative average yield (2012 to 2016 mean yield) (Table 5). The relatively high heritability estimates for growth traits suggested that selection for these traits could start in early generations of breeding. In comparing the vegetative growth traits, the pronounced environmental effect on some traits (number of laterals, span and height) performance was reflected in low $(\leq 0.20)$ heritability estimates (Table 5$)$. The high environmental (error) variance component, which led to low heritability estimates for these traits could, in part, be attributable to high plot-to-plot variation on account of the small number of trees planted per clone per block in the current study. Therefore, increased sampling of the experimental area through increased number of trees per block, might be required to increase the precision of observed differences and minimize the error variance to obtain higher heritability estimates for traits such as height, number of laterals, span and yield. A higher broad-sense heritability was observed for early yields (2012/2013 mean) than for mean yield across five years (Table 5). This suggested that selection for high-yielding Robusta coffee clones in the early years of production might be more effective than selection in later years. This might also suggest that because single-tree randomization was used, competition in later years had a more pronounced effect on clone yield variation between blocks than in the early years of yield estimation when trees were relatively smaller.

The phenotypic coefficient of variation (PCV) was higher than the genotypic coefficient of variation (GCV) for all traits studied (Table 5). The higher PCV than GCV again reflects the high environmental influence on expression of the studied traits. The higher PCV than GCV observed for the traits evaluated was not unique to this experiment, as similar observations have been made in studies on Arabica coffee (Ermias, 2005; Gray et al., 2013). The GCV provides a measure for comparing genetic variability in quantitative traits, and together with heritability estimates determines the extent of heritable variation and hence the potential to improve a trait (Burton, 1952; Valois et al., 1980). The estimated GCV values in the present study ranged from $7.1 \%$ for span to $59.3 \%$ for mean yield for the first two yield recording years (Table 5). The high GCV value estimated, particularly for early yield (mean yield of the first two production years) indicated a high probability of success of selection for this trait as posited by Falconer and Mackay (1996) (Table 5).

Heritability provides the basis for predicting response to selection and the response to selection or genetic advance in turn defines the expected progress to be made from selection above a population mean at a given selection intensity (Singh \& Chaudhary, 2001). Means and expected genetic advance as percentage of trait mean, under selection with varying selection intensities $(2,5,10,20$ and 30\%) for all traits assessed are presented in Table 6 . For any given trait, genetic advance at $2 \%$ selection intensity was about twice that at $30 \%$ selection intensity, and intermediate at $10 \%$ selection intensity. Among all the traits assessed, there was a superior genetic advance for early yield (first 2 years' mean yield), regardless of the selection intensity (Table 6). Johnson et al. (1955) suggested that heritability estimates together with genetic advance were more useful in predicting the resulting effect of selection. Similarly, Abebe et al. (2017) argues that knowledge about heritability coupled with 
genetic advance and genotypic coefficient of variations are most useful in predicting selection effects. Thus, in the present study, the moderate heritability $(0.30 \pm 0.09)$ and relatively high GCV (59.3) and the high genetic advance for the mean yield of the first 2 years, regardless of the selection intensity, suggested that selection would be highly effective in improving this trait. In general, the moderate heritability estimates, GCV values and the relatively high genetic advance estimates (Tables 5 and 6) for all traits assessed, indicated that it is possible to obtain desirable gains from selection for all traits assessed in the present study, except for span which had low heritability $(0.16 \pm 0.03)$, the least GCV (7.1) and the least genetic advance estimates, regardless of the selection intensity.

Table 6. Means and expected genetic advance (Gs) under varying selection intensities for various traits assessed

\begin{tabular}{|c|c|c|c|c|c|c|}
\hline \multirow{3}{*}{ Trait } & \multirow{3}{*}{ Mean } & \multicolumn{5}{|c|}{ Expected genetic advance } \\
\hline & & \multicolumn{5}{|c|}{ Selection intensity (\%) } \\
\hline & & 2 & 5 & 10 & 20 & 30 \\
\hline Diameter of laterals (mm) & 5.3 & 17.7 & 15.0 & 12.8 & 10.2 & 8.5 \\
\hline Stem diameter $(\mathrm{mm})$ & 34.2 & 15.1 & 12.8 & 11.0 & 8.7 & 7.2 \\
\hline Height (m) & 1.6 & 9.1 & 7.7 & 6.6 & 5.2 & 4.3 \\
\hline Length of laterals (m) & 0.9 & 17.3 & 14.7 & 12.6 & 10.0 & 8.3 \\
\hline Number of laterals & 41 & 13.1 & 11.2 & 9.5 & 7.6 & 6.3 \\
\hline Span (m) & 1.5 & 7.0 & 6.0 & 5.1 & 4.0 & 3.4 \\
\hline $\mathrm{Y} 12 / 13(\mathrm{t} / \mathrm{ha} / \mathrm{yr})$ & 0.5 & 78.0 & 66.4 & 56.7 & 45.1 & 37.4 \\
\hline Y14-16 (t/ha/yr) & 2.2 & 16.2 & 13.8 & 11.8 & 9.4 & 7.8 \\
\hline Y12-16 (t/ha/yr) & 1.6 & 19.8 & 16.8 & 14.4 & 11.4 & 9.5 \\
\hline
\end{tabular}

Note. Y12/13 (t/ha/yr) = 2012 and 2013 mean yield; Y14-16(t/ha/yr) = 2014 to 2016 mean yield; Y12-16 (t/ha/yr)

$=2012$ to 2016 mean yield; Expected genetic advance is expressed as a percentage of the trait mean.

\section{Conclusions}

Significant variation was observed among 54 Robusta coffee clones developed by ortet selection from an earlier hybrid trial and evaluated for vegetative growth and yield traits. The study revealed that selection for yield could be more effective in the early years of production than in later years because there was a higher heritability for early years' yield than yield in later years and 5-year mean yield. The environment had an effect on the expression of all the traits assessed as the environmental variance component was higher than the genotypic variance component for all traits. However, the moderate broad-sense heritability estimates for the growth and yield traits and the reasonably high expected genetic advance values obtained under selection intensities of 2 to $30 \%$ suggested that appreciable progress could be made in improving these traits through selection. The top 10 high-yielding clones identified in this study could be considered for direct utilization by farmers or as parental clones in breeding for genetic improvement of Robusta coffee in Ghana. Results showed that genetic parameters were important in the improvement of growth traits as well as yield if selection for yield is practiced in early years in a coffee breeding program.

\section{Acknowledgements}

The authors gratefully thank the field and technical staff of the Plant Breeding Division of CRIG, for their support and assistance, especially Mr. Lawrence Offei, Mr. Gift Gazo, Mrs. Diana Ohene Asare and Mrs. Gifty Amoako. This paper is published with the kind permission of the Executive Director of Cocoa Research Institute of Ghana as manuscript number CRIG/09/2018/034/002.

\section{References}

Abebe, T., Alamerew, S., \& Tulu, L. (2017). Genetic variability, heritability and genetic advance for yield and its related traits in rainfed lowland rice (Oryza sativa L.) genotypes at Fogera and Pawe, Ethiopia. Adv. Crop Sci. Tech., 5, 272. http://doi.org/10.4172/2329-8863.1000272

Adu, S. V., \& Asiamah, R. D. (1992). Soils of the Ayensu-Densu basin (Memoir No. 9). Soil Research Institute/Council for Scientific and Industrial Research. Kumasi, Ghana. 
Anim-Kwapong, E., \& Anim-Kwapong, G. J. (2012). Indirect and direct selection for yield in Coffea canephora genotypes under drought-stress and non-stress conditions. J. Crop Improv., 26, 489-502. http://doi.org/ $10.1080 / 15427528.2011 .652294$

Anim-Kwapong, E., Anim-Kwapong, G. J., \& Adomako, B. (2011a). Indirect versus direct selection of adaptable genotypes of Coffea canephora for drought stress and non-stress conditions. J. Crop Improv., 25, 356-370. http://doi.org/10.1080/15427528.2011.569474

Anim-Kwapong, E., Anim-Kwapong, G. J., \& Adomako, B. (2011b). Variation and association among characters genetically related to yield and yield stability in Coffea canephora genotypes. J. Plant Breed. Crop Sci., 3, 311-320. http://doi.org/10.5897/JPBCS11.054

Barros, R. S., Maestri, M., \& Rena, A .B. (1999). Physiology of growth and production of the coffee tree - a review. J. Coffee Res., 27, 1-54.

Betrán, F. J., Ribaut, J. M., Beck, D., \& Gonzalez de León, D. (2003). Genetic diversity, specific combining ability, and heterosis in tropical maize under stress and nonstress environments. Crop Sci., 43, 797-806. http://doi.org/10.2135/cropsci2003.7970

Bouharmont, P., Lotode, R., Awemo, J., \& Castaing, X. (1986). La sélection générative du caféier Robusta au Cameroun. Analyse des re'sultats d'un essai d'hybrides dialle 'le partiel implante' en 1973. Cafe Cacao The, 30, 93-112.

Brown, J., Calgari, P. D. S., Dale, M. F. B., Swan, G. E. L., \& Mackay, G. R. (1988). The use of cross prediction methods in a practical potato breeding programme. Theor. Appl. Genet., 76, 33-38. http://doi.org/10.1007/ BF00288828

Burton, G. W. (1952). Quantitative inheritance in grasses. Grassland Congress In: Proceedings of the 6th International Grassland Congress, 1, 227-283.

Cilas, C., Bar-hen, A., Montagnon, C., \& Godin, C. (2006). Definition of architectural ideotypes for good yield capacity in Coffea canephora. Ann. Bot., 97, 405-411. http://doi.org/10.1093/aob/mcj053

Cilas, C., Bouharmont, P., \& Bar-hen, A. (2003). Yield stability in Coffea canephora from diallel mating designs monitored for 14 years. Heredity, 91, 528-532. http://doi.org/10.1038/sj.hdy.6800351

Cilas, C., Bouharmont, P., Boccara, M., Eskes, A. B., \& Baradat, P. (1998). Prediction of genetic value for coffee production in Coffea arabica from a half-diallel with lines and hybrids. Euphytica, 104, 49-59. http://doi.org/10.1023/A:1018635216182

Cilas, C., Montagnon, C., Bertrand, B., \& Godin, C. (2000). Wood elasticity of several Coffea canephora clones. A new trait to be included in selection schemes. Agronomie, 20, 439-444. http://doi.org/10.1051/agro: 2000140

Coste, R. (1992). Coffee: The Plant and the Product (pp. 206-328). The Macmillan Press Ltd, London and Basingstoke, U.K.

DaMatta, F. M., Ronchi, C. P., Maestri, M., \& Barros, R. S. (2007). Ecophysiology of coffee growth and production. Braz. J. Plant Physiol., 19, 485-510. https://doi.org/10.1590/S1677-04202007000400014

DaMatta, M. F., \& Ramalho, J. D. C. (2006). Impacts of drought and temperature stress on coffee physiology and production: A review. Braz. J. Plant Physiol., 18, 55-81. https://doi.org/10.1590/S1677-042020060 00100006

Dias, L. A. S., Marita, J., Cruz, C. S., de Barros, E. G., \& Salomão, T. M. F. (2003). Genetic distance and its association with heterosis in cacao. Braz. Arch. Biol. Technol., 46, 339-348. https://doi.org/10.1590/ S1516-89132003000300005

Ermias, H. (2005). Evaluation of Wellega coffee germplasm for yield, yield components and resistance to coffee berry disease at early bearing stage (A Thesis Submitted to the faculty of the Department of Plant Sciences, School of Graduate Studies. Alemaya University, Ethiopia).

Falconer, D. S. (1974). Introduction to quantitative genetics (p. 284). Paris, France: Masson.

Falconer, D. S., \& Mackay, T. F. C. (1996). Introduction to quantitative genetics (4th ed.). Addison Wesley Longman, London, Essex, UK.

Fonseca, A. F. A. (1999). Análises biométricas em café conillon (Coffea canephora Pierre) (p. 121, PhD Thesis, Universidade Federal de Viçosa, Viçosa). 
Gray, Q., Tefera, A., \& Tefera, T. (2013). Ethiopia: Coffee Annual Report. GAIN Report No. ET 1302.

ICO (International Coffee Organization). (2016). Trade statistics. Retrieved June 27, 2017, from http://www.ico.org/monthly_coffee_trade_stats.asp

Johnson, H. W., Robinson, H. F., \& Comstock, R. E. (1955). Estimates of genetic and environmental variability in soybeans. Agron. J., 47, 314-318. https://doi.org/10.2134/agronj1955.00021962004700070009x

Kang, M. S., Miller, J. D., \& Tai, P. Y. P. (1983). Genetic and phenotypic path analyses and heritability in sugarcane. Crop Sci., 23, 643-647. https://doi.org/10.2135/cropsci1983.0011183X002300040010x

Kawano, K., Narintaraporn, K., Narintaraporn, P., Sarakarn, S., Limsila, A., Limsila, J., ... Wantananonta, W. (1998). Yield improvement in multistage breeding program for cassava. Crop. Sci., 38, 325-332. https://doi.org/10.2135/cropsci1998.0011183X003800020007x

Leroy, T., Montagnon, C., Cilas, C., Charrier, A., \& Eskes, A. B. (1993). Reciprocal recurrent selection applied to Coffea canephora Pierre. II. Estimation of genetic parameters. Euphytica, 74, 121-128. http://doi.org/ 10.1007/BF00033776

Leroy, T., Montagnon, C., Cilas, C., Yapo, A., Charmetant, P., \& Eskes, A. B. (1997). Reciprocal recurrent selection applied to Coffea canephora Pierre. III. Genetic gains and results of first cycle intergroup crosses. Euphytica, 95, 347-354. http://doi.org/10.1023/A:1003074716379

Marandu, E. F. T., Reuben, S. O. W., \& Misangu, R. N. (2004). Genotypic correlations and paths of influence among components of yield in selected Robusta coffee (Coffea canephora L.) clones. West African Journal of Applied Ecology, 5, 11-20. https://doi.org/10.4314/wajae.v5i1.45596

Medina-Filho, H. P., Maluf, M. P., Bordignon, R., Guerreiro-Filho, O., \& Fazuoli, L.C. (2007). Traditional breeding and modern genetics: A summary of tools and developments to exploit biodiversity for the benefit of the coffee agro-industrial chain. Acta Hort., 745, 351-368. https://doi.org/10.17660/ActaHortic. 2007.745.21

Mistro, J. C., Fazuoli, L. C., de Souza Gonçalves, P., \& Filho, O. G. (2004). Estimates of genetic parameters and expected genetic gains with selection in robust coffee. Crop Breed. Appl. Biotechnol., 4, 86-91. http://doi.org/10.12702/1984-7033.v04n01a14

Montagnon, C., Cilas, C., Leroy, T., Yapo, A., \& Charmentant, P. (2000). Genotype-location interactions for Coffea canephora yield in the Ivory Coast. Agronomie, 20, 101-109. http://doi.org/10.1051/agro:2000110

Montagnon, C., Leroy, T., \& Eskes, A. B. (1998). Amelioration varietale de Coffea canephora. I. Crite'res et methodes de selection. Plantations, Recherches, De'veloppement, 5, 18-33.

Montagnon, C., Leroy, T., Cilas, C., \& Charrier, A. (2003). Heritability of Coffea canephora yield estimated from several mating designs. Euphytica, 133, 209-218. http://doi.org/10.1023/A:1025543805652

Oliveira, E. J., Santos, V. S., Lima, D. S., Machado, M. D., Lucena, R. S., Motta, T. B. N., \& Castellen, M. S. (2008). Seleção em progênies de maracujazeiro amarelo com base em índices multivariados. Pesq. Agropec. Bras., 43, 1543-1549. https://doi.org/10.1590/S0100-204X2008001100013

Prakash, N. S., Combes, M. C., Dussert, S., Naveen, S., \& Lashermes, P. (2005). Analysis of genetic diversity in Indian Robusta coffee genepool (Coffea canephora) in comparison with a representative core collection using SSRs and AFLPs. Genet. Resour. Crop Ev., 52, 333-342. http://doi.org/10.1007/s10722-003-2125-5

Reuben, S. O. W. M., Marandu, E. F. Y., \& Misangu, R. N. (2003). Agronomic performance and heritability of some yield components of Robusta coffee (Coffea canephora Pierre ex Froehner) clones. Tanzania J. Agric. Sc., 1, 45-54. https://www.ajol.info/index.php/tjags/article/view/115222

Riaz, A., Li, G., Quresh, Z., Swati, M. S., \& Quiros, C. F. (2001). Genetic diversity of oilseed Brassica napus inbred lines based on sequence-related amplified polymorphism and its relation to hybrid performance. Plant Breeding, 120, 411-415. http://doi.org/10.1046/j.1439-0523.2001.00636.x

Sera, T. (2001). Coffee genetic breeding at IAPAR. Crop Breed. Appl. Biotechnol., 1, $179-200$. http://doi.org/10.13082/1984-7033.v01n02a08

Singh, R. K., \& Chaudhary, B. D. (2001). Plant Breeding: Principles and methods. Kalyani publishers, New Delhi, pp. 896.

Srinivasan, C. S., Vihveshwara, S., \& Subramanya, H. (1979). Genotype-Environment interaction and heritability of yield in Coffea arabica L. J. Coffee Res., 9, 69-73. 
Stewart, J. L., \& Salazar, R. (1992). A review of measurement options for multipurpose trees. Agrofor. Syst., 19, 173-183. http://doi.org/10.1007/BF00138507

Valois, A. C. C., Schmidt, G. S., \& Sanotto, M. D. (1980). Análise de qualidade e quantidade de grãos em população de milho (p. 53). ESALQ, Piracicaba.

Vencovsky, R. (1987). Herança quantitativa. In E. Paterniani \& G. P. Viegas (Eds.), Melhoramento e produção do milho (2nd ed., pp. 137-214). Fundação Cargill, Campinas.

Walyaro, D. J. (1983). Considerations in breeding for improved yield and quality in Arabica coffee (Coffea arabica L.) (p. 121, Doctoral thesis, University of Agriculture, Wageningen, The Netherlands).

Walyaro, D. J., \& Van Der Vossen, H. A. M. (1979). Early determination of yield potential in Arabica coffee by applying index selection. Euphytica, 28, 465-472. https://doi.org/10.1007/BF00056606

Wassu, M. (2011). Magnitude of exploitable heterosis for yield and quality traits of coffee (Coffea arabica L.) hybrids as affected by distant parents in origin and morphology in Ethiopia. East African Journal of Sciences, 5, 22-36. Retrieved from https://www.ajol.info/index.php/eajsci/article/view/101811

Wellman, F. L. (1961). Coffee, botany, cultivation and utilization. Leonard Hill Books, London.

Willson, K. C. (1999). Coffee, Cocoa and Tea. CAB International, Wallingford.

\section{Copyrights}

Copyright for this article is retained by the author(s), with first publication rights granted to the journal.

This is an open-access article distributed under the terms and conditions of the Creative Commons Attribution license (http://creativecommons.org/licenses/by/4.0/). 